\title{
A systematic review of the effects of impaired glucose tolerance (IGT) on the incidence of chronic kidney disease (CKD) in young adults
}

FEROZKHAN JADHAKHAN, TOM MARSHALL, PARAMJIT GILL

\begin{abstract}
Objective: The risk of chronic kidney disease (CKD) is elevated in patients with diabetes mellitus but the effect of impaired glucose tolerance (IGT) is not known. This systematic review investigates the risk of CKD associated with IGT in young adults aged $18-40$ years.

Methods: CINAHL, EMBASE, MEDLINE, PubMed, Cochrane libraries and grey literature were searched from inception to January $\mathbf{2 0 1 5}$ without language restriction for case-control and cohort studies comparing the frequency of CKD in cases aged 18-40 years with IGT/IFG (impaired fasting glucose) with controls without glycaemic abnormality or with type 2 diabetes (T2DM). CKD outcomes were determined by: estimated glomerular filtration rate, albumin creatinine ratio, proteinuria $\geq 1$, serum creatinine, protein creatinine ratio and creatinine clearance levels.

Results: Initial searches identified 90 citations potentially meeting the inclusion criteria. After full text review, 19 cohort studies and no case-control studies met the inclusion criteria, but only one cohort study reported separate data for persons aged 18-40 years. This study only compared the incidence of CKD in individuals with IGT with those with T2DM. The annual incidence of CKD was $0.13 \%$ per personyear compared with $2.4 \%$ in patients with T2DM.

Conclusion: The results of this systematic review demonstrate that the risk of CKD in young adults with IGT/IFG is lacking. Further research is needed to estimate the incidence of CKD in this cohort of individuals. To bridge this gap in evidence, large epidemiological databases may be examined to quantify the risk of CKD in young adults aged 18-40 years with IGT/IFG compared with those with normoglycaemia.
\end{abstract}

Primary Care Clinical Sciences, Institute of Applied Health Research, University of Birmingham, Birmingham, UK

Address for correspondence: Mr Ferozkhan Jadhakhan Primary Care Clinical Sciences, Institute of Applied Health Research, University of Birmingham, Birmingham B15 2TT, UK

Tel: +44 (0)1214143758

E-mail: fxj733@bham.ac.uk

http://dx.doi.org/10.15277/bjd.2016.105
Data from these databases may potentially inform a prognostic study which may be useful in understanding the course and factors associated with CKD development. Finally, the results may emphasise the importance of identifying individuals with IGT/IFG earlier and implementing interventions to prevent or delay the development of CKD.

Br J Diabetes 2016;16:162-167

Key words: impaired glucose tolerance, chronic kidney disease, estimated glomerular filtration rate, albumin creatinine ratio, type 2 diabetes

\section{Introduction}

Chronic kidney disease (CKD) is a long-term condition characterised by the presence of kidney damage and/or a gradual loss of kidney function. ${ }^{1}$ Diabetes is a leading cause of CKD due to either diabetic nephropathy or vascular damage. A prospective cohort study conducted in England and Wales found the hazard of developing CKD in patients aged 35-74 years was five times higher in women and six times higher in men with diabetes than in those with normal glucose tolerance. ${ }^{2}$

Pre-diabetes indicates both impaired fasting glucose (IFG) and impaired glucose tolerance (IGT), collectively known as impaired glucose regulation (IGR). Individuals with IGR have a blood glucose raised beyond the normal level but not high enough for a diabetes diagnosis. ${ }^{3}$ Furthermore, the risk of young adults aged 18-40 years with IGT developing CKD is not well characterised. Despite the heavy burden of cardiovascular disease (CVD) including CKD, very few studies have evaluated the CVD risk profile in young adults using a prediction algorithm such as the Framingham risk score or QRISK. There is some evidence that the incidence of CKD is elevated in individuals with IGT; however, this is often confined to a specific population. ${ }^{4}$ It is not clear whether the risk of CKD is elevated in patients with IGT or whether any increased risk only occurs after patients develop diabetes. Crosssectional studies show that albuminuria - an early marker of CKD - was approximately three times more common in patients with IGT than in those with normoglycaemia. ${ }^{.}$These data are subject to some limitations, as it is unclear whether CKD precedes impaired glucose metabolism or vice versa. The purpose of this systematic review is to find out whether the presence of 
IGT in young adults aged 18-40 years is associated with an increased risk of CKD by comparing the risk of CKD in individuals with IGT and those without IGT, and also to evaluate whether any increased risk occurs only after they develop type 2 diabetes (T2DM).

\section{Methods}

Established guidelines for reviews were used to inform the search strategy, selection of studies, assessment of risks of bias and reporting of results. 6,7 The comparison groups were either participants with normoglycaemia or those with confirmed diabetes. The review protocol has been published elsewhere. ${ }^{8}$

\section{Eligibility criteria}

\section{Types of participants and comparison group}

This review includes studies where some participants are aged 1840 years and results reported separately in this age group without a diagnosis of type 1 and type 2 diabetes but with IGT, 'prediabetes' or 'pre-diabetic state'. IGT/IFG can be referred to as prediabetes, ${ }^{9}$ or metabolic syndrome where IGT is part of the metabolic syndrome. The comparison group was either participants with normoglycaemia or patients with diabetes. For the purpose of this review, IGT was classified as a fasting plasma glucose (FPG) $<7 \mathrm{mmol} / \mathrm{L}(<126 \mathrm{mg} / \mathrm{dL}$ ) or an oral glucose tolerance test (OGTT) $\geq 7.8 \mathrm{mmol} / \mathrm{L}$ and $<11.1 \mathrm{mmol} / \mathrm{L}(140-200 \mathrm{mg} / \mathrm{dL})$ or glycated haemoglobin $\left(\mathrm{HbA}_{1 \mathrm{c}}\right.$ ) of $5.7-6.4 \%(42-47 \mathrm{mmol} / \mathrm{mol})$, and IFG was defined as FPG 5.6-6.9 mmol/L (100-125 mg/dL) and $\mathrm{HbA}_{1 \mathrm{c}} 5.7-$ $6.4 \% .10$

\section{Participants and outcomes - cohort studies}

This review includes any cohort studies where some participants are aged 18-40 years and results are reported separately in this age group with (1) IGT/IFG (exposed group) compared with participants without glycaemic abnormality (comparator); or (2) IGT/IFG but without a diagnosis of type 1 diabetes compared with participants with T2DM. Participants were free from CKD at baseline. A broad range of measures was used to ascertain CKD (outcome). This included estimated glomerular filtration rate (eGFR) stages 3A, 3B, 4 and 5; albuminuria; albumin creatinine ratio (ACR; $\geq 2.5 \mathrm{mg} / \mathrm{mmol}$ or $\geq 30 \mathrm{mg} / \mathrm{g}$ ); protein creatinine ratio ( $P C R \geq 45 \mathrm{mg} / \mathrm{mmol}$ or $\geq 300 \mathrm{mg} / \mathrm{g}$ ); serum creatinine (SCr; $1.0 \mathrm{mg} / \mathrm{dL}$ or $\geq 50 \mu \mathrm{mol} / \mathrm{L})$, proteinuria $(\geq 1+)$ and creatinine clearance $(\mathrm{CrCl} ; \geq 60 \mathrm{ml} / \mathrm{min})$. Studies reporting mean changes in continuous variables (e.g. eGFR) were also included. Studies reporting a single measure instead of two measures of eGFR or only by any of the above measures were included. Measures of association (HR, OR, IRR and RR) were extracted and reported or sufficient information to calculate these figures.

\section{Participants and outcomes - case-control studies}

This review also includes any case-control studies in which some cases were aged 18-40 years with an incident diagnosis of CKD (the outcome of interest) by any of the above definitions and controls without a diagnosis of CKD. The frequency of previous IGT/IFG (exposure to IGT/IFG) was compared with either the frequency of normoglycaemia (unexposed) or the frequency of diabetes (an alternative exposure). There was no restriction on the length of participant follow-up.

\section{Search strategy and data extraction}

The following electronic databases were systematically searched without language restriction from inception to January 2015: MEDLINE, Cumulative Index to Nursing and Allied Health Literature (CINAHL), EMBASE, PubMed, Database of Abstracts of Reviews of Effects (DARE), Cochrane Database of Systematic Reviews (CDSR), Trip Database and Google Scholar. Ongoing studies, scientific literature and abstract proceedings were identified by searching the following databases: ClinicalTrials.gov, Cochrane Renal Group specialised register, Renal Registry Database, British Renal Society, Renal Association, American Society of Nephrology, World Congress of Nephrology, Diabetes UK Conference, Primary Care Diabetes Society Conference and Zetoc. A comprehensive search of the Conference Proceedings Citation Index (CPCI) was also carried out. Search of these databases spanned from January 2011 to January 2014 as it is likely that studies would have been completed and published. Grey literature databases such as Grey Literature Report, OpenGrey, Publicat and ScienceDaily.com were examined. Open access theses and dissertations were retrieved from the ProQuest Dissertation Thesis Database and thesis.com. The Science Citation Index (SCI) was used to scan and track study titles. The search strategy is shown in Appendix 1 (available online at bjd-abcd.com).

Two reviewers independently reviewed all titles and abstracts in two phases. First the retrieved titles and abstracts were reviewed to identify relevant studies. The full texts of retrieved studies were then read to determine eligibility. Any discrepancies or differences in opinion were resolved by consensus. An inclusion criteria checklist (Appendix 2 available online at bjd-abcd.com) was developed based on study eligibility criteria piloted on five papers.

\section{Quality assessment}

Study quality was assessed according to a modified tool based on the Ottawa-Newcastle scale (NOS). ${ }^{11}$ Risk of bias was assessed on the following domains: (1) sampling; (2) outcome measurement; (3) attrition; (4) analytical method; and (5) confounders (Appendix 3 available online at bjd-abcd.com). A composite score was not provided; instead, a risk of bias of 'yes' indicating adequate data were provided, 'no' if data were provided but did not meet the criteria for that domain and 'unclear' potentially at high risk of bias. ${ }^{12}$

\section{Publication bias}

If sufficient studies are identified for future updates, the Begg's ${ }^{13}$ and Egger's ${ }^{14}$ regression test will be carried out to detect publication bias. At least 10 studies will be needed to sufficiently detect publication bias. ${ }^{15}$ Studies will be grouped according to effects measures and reporting risk of CKD determined by any of the measures listed above.

\section{Results}

Search results

Initial database searches identified 5,568 studies. After scanning 
Table 1 Quality assessment of included studies: IGT/IFG compared with normoglycaemia

\begin{tabular}{|c|c|c|c|c|c|c|c|c|c|c|}
\hline Study & $\begin{array}{l}\text { Selection of } \\
\text { participants }\end{array}$ & $\begin{array}{l}\text { Adequate } \\
\text { description } \\
\text { of study } \\
\text { population }\end{array}$ & $\begin{array}{l}\text { Validated } \\
\text { method } \\
\text { to } \\
\text { ascertain } \\
\text { exposure }\end{array}$ & $\begin{array}{l}\text { Validated } \\
\text { method } \\
\text { to } \\
\text { confirm } \\
\text { outcome }\end{array}$ & $\begin{array}{l}\text { Adequate } \\
\text { follow-up }\end{array}$ & $\begin{array}{l}\text { Completeness } \\
\text { of follow-up } \\
\text { (attrition) }\end{array}$ & $\begin{array}{l}\text { Analysis } \\
\text { control } \\
\text { for } \\
\text { confounding }\end{array}$ & $\begin{array}{l}\text { Sample } \\
\text { size } \\
\text { calculation }\end{array}$ & $\begin{array}{l}\text { Analytical } \\
\text { methods } \\
\text { appropriate }\end{array}$ & $\begin{array}{l}\text { Adjustment } \\
\text { for } \\
\text { confounders }\end{array}$ \\
\hline $\begin{array}{l}\text { Nelson et al } \\
(1996)^{17}\end{array}$ & Yes & Yes & Yes & Yes & Yes & Yes & Yes & Unclear & YES & None \\
\hline $\begin{array}{l}\text { Fox et al } \\
(2005)^{4}\end{array}$ & Yes & Yes & Yes & Yes & Yes & Unclear & Yes & No & Yes & $\begin{array}{l}\text { Age, sex, } \\
\text { baseline GFR, } \\
\text { SBP, hypertension } \\
\text { treatment, } \\
\text { smoking, BMI, } \\
\text { total and HDL } \\
\text { cholesterol, MI, } \\
\text { congestive } \\
\text { heart failure }\end{array}$ \\
\hline $\begin{array}{l}\text { Meigs et al } \\
(2002)^{18}\end{array}$ & Yes & Yes & Yes & Yes & Yes & Unclear & Yes & No & Yes & $\begin{array}{l}\text { Age, SBP, BMI, } \\
\text { smoking, ACE } \\
\text { inhibitor, total } \\
\text { cholesterol, HDL, } \\
\text { triglyceride, } \\
\text { hypertensive } \\
\text { drugs. }\end{array}$ \\
\hline $\begin{array}{l}\text { Nelson et al } \\
(1999)^{19}\end{array}$ & Yes & Yes & Yes & Yes & Yes & Unclear & Yes & No & Yes & None \\
\hline $\begin{array}{l}\text { Nelson et al } \\
(1989)^{20}\end{array}$ & Yes & Yes & Yes & Yes & Yes & Yes & Yes & No & Yes & Age, sex, BP \\
\hline $\begin{array}{l}\text { Yokoyama et al } \\
(2009)^{21}\end{array}$ & IYes & Yes & Yes & Yes & No & Unclear & Yes & No & Yes & None \\
\hline $\begin{array}{l}\text { Tozawa et al } \\
(2007)^{22}\end{array}$ & Yes & Yes & Yes & Yes & Yes & No & Yes & No & Yes & $\begin{array}{l}\text { Age, sex, current } \\
\text { cigarette } \\
\text { smoking, alcohol } \\
\text { drinking habit }\end{array}$ \\
\hline $\begin{array}{l}\text { Nelson et al } \\
(1993)^{23}\end{array}$ & Yes & Yes & Yes & Yes & Yes & Unclear & Yes & No & Yes & None \\
\hline $\begin{array}{l}\text { Rashidi et al } \\
(2007)^{24}\end{array}$ & Yes & Yes & Yes & Yes & Yes & Unclear & Yes & No & Yes & None \\
\hline $\begin{array}{l}\text { Kitiyakara et al } \\
(2007)^{25}\end{array}$ & Yes & Yes & Yes & Yes & Yes & No & Yes & No & Yes & $\begin{array}{l}\text { Age, sex and } \\
\text { smoking status }\end{array}$ \\
\hline $\begin{array}{l}\text { Sun et al } \\
(2010)^{26}\end{array}$ & Yes & Yes & Yes & Yes & Yes & Yes & Yes & No & Yes & $\begin{array}{l}\text { Age, sex, } \\
\text { check-up centers } \\
\text { and current } \\
\text { smoking }\end{array}$ \\
\hline $\begin{array}{l}\text { Yang et al } \\
(2012)^{27}\end{array}$ & Yes & Yes & Yes & Yes & Yes & No & Yes & No & Yes & $\begin{array}{l}\text { Age, sex, BMI, } \\
\text { serum level, } \\
\text { total cholesterol, } \\
\text { BP, triglyceride, } \\
\text { HDL, waist } \\
\text { circumference }\end{array}$ \\
\hline $\begin{array}{l}\text { Kovács et al } \\
(2013)^{28}\end{array}$ & Yes & Yes & Yes & Yes & Yes & Unclear & Yes & No & Yes & No adjustments \\
\hline $\begin{array}{l}\text { Watanabe et al } \\
(2010)^{29}\end{array}$ & Yes & Yes & Yes & Yes & Yes & No & Yes & No & Yes & Sex and age \\
\hline $\begin{array}{l}\text { Ryu et al } \\
(2009)^{30}\end{array}$ & Yes & Yes & Yes & Yes & Unclear & No & Yes & No & Yes & $\begin{array}{l}\text { Age, baseline } \\
\text { GFR, glutamyl- } \\
\text { transpeptide, } \\
\text { uric acid, } \\
\text { triglyceride, HDL } \\
\text { cholesterol, BP, } \\
\text { obesity }\end{array}$ \\
\hline $\begin{array}{l}\text { Tohidi et al } \\
(2012)^{32}\end{array}$ & Yes & Yes & Yes & Yes & Yes & Unclear & Yes & No & Yes & $\begin{array}{l}\text { BMI, total } \\
\text { cholesterol, SBP }\end{array}$ \\
\hline $\begin{array}{l}\text { Jee et al } \\
(2005)^{31}\end{array}$ & Yes & Yes & Yes & Yes & Yes & No & Yes & No & Yes & None \\
\hline
\end{tabular}

BP, blood pressure; BMI, body mass index; DBP, diastolic blood pressure; GFR, glomerular filtration rate; IFG, impaired fasting glucose; IGT, impaired glucose tolerance; HDL, high density lipoprotein; MI, myocardial infarction; SBP, systolic blood pressure. 
Table 2 Quality assessment of included studies: IGT/IFG compared with T2DM

\begin{tabular}{|c|c|c|c|c|c|c|c|c|c|c|}
\hline Study & $\begin{array}{l}\text { Selection of } \\
\text { participants }\end{array}$ & $\begin{array}{l}\text { Adequate } \\
\text { description } \\
\text { of study } \\
\text { population }\end{array}$ & $\begin{array}{l}\text { Validated } \\
\text { method } \\
\text { to } \\
\text { ascertain } \\
\text { exposure }\end{array}$ & $\begin{array}{l}\text { Validated } \\
\text { method } \\
\text { to } \\
\text { confirm } \\
\text { outcome }\end{array}$ & $\begin{array}{l}\text { Adequate } \\
\text { follow-up }\end{array}$ & $\begin{array}{l}\text { Completeness } \\
\text { of follow-up } \\
\text { (attrition) }\end{array}$ & $\begin{array}{l}\text { Analysis } \\
\text { control } \\
\text { for } \\
\text { confounding }\end{array}$ & $\begin{array}{l}\text { Sample } \\
\text { size } \\
\text { calculation }\end{array}$ & $\begin{array}{l}\text { Analytical } \\
\text { methods } \\
\text { appropriate }\end{array}$ & $\begin{array}{l}\text { Adjustment } \\
\text { for } \\
\text { confounders }\end{array}$ \\
\hline $\begin{array}{l}\text { Kim et al } \\
(2010)^{16}\end{array}$ & Yes & Yes & Yes & Yes & Yes & Unclear & Yes & No & Yes & Age and sex \\
\hline $\begin{array}{l}\text { Iseki et al } \\
(2004)^{33}\end{array}$ & Yes & Yes & Yes & Yes & Yes & Unclear & Yes & No & Yes & $\begin{array}{l}\text { Age, sex, baseline } \\
\text { GFR, SBP, DBP, BMI, } \\
\text { total cholesterol, } \\
\text { triglyceride, serum } \\
\text { creatinine, haematuria } \\
\text { and proteinuria }\end{array}$ \\
\hline
\end{tabular}

BP, blood pressure; BMI, body mass index; DBP, diastolic blood pressure; GFR, glomerular filtration rate; HDL, high density lipoprotein; IFG, impaired fasting glucose; IGT, impaired glucose tolerance; MI, myocardial infarction; SBP, systolic blood pressure.

Figure 1. Study selection and reasons for exclusion

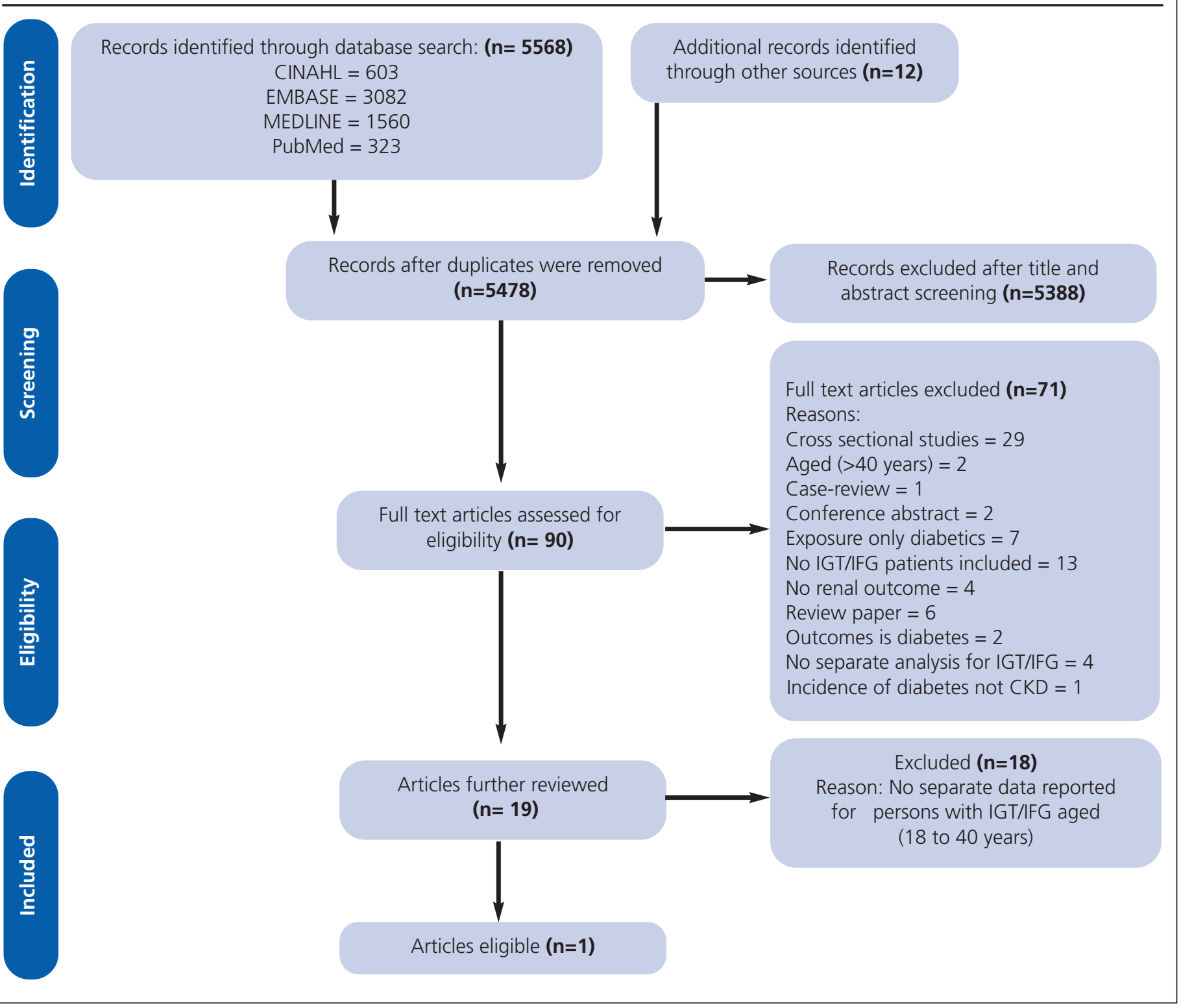


the titles, 90 citations potentially met the inclusion criteria. These were reviewed in detail (full text) and 19 cohort studies were selected for further review (no case-control studies were selected). A summary of the overall quality of the 19 studies is provided in Table 1 and 2 . Only one of the 19 cohort studies reported separate data for persons aged 18-40 years. This study compared the incidence of CKD in patients with IGT and those with T2DM. A PRISMA study flow diagram of included and excluded studies is provided along with reasons for exclusion in Figure 1. Data from this study were reported narratively.

\section{Study characteristics}

The characteristics of the 19 cohort studies are summarised in Appendix 4 and 5 (available online at bjd-abcd.com). Briefly, no case-control studies meeting the inclusion criteria were identified. Nineteen cohort studies were identified. One reported separate data in persons aged 18-40 years with IGT compared with T2DM.

\section{Incidence of CKD in persons aged $18-40$ years with IGT compared with T2DM}

Kim et al reported the risk of CKD in young adults aged 18-40 years with IGT compared with T2DM. ${ }^{16}$ This cohort study followed 2,666 Pima Indian young adults aged $\leq 20$ years with IGT and T2DM during a follow-up period of 25.2 years for the development of macroalbuminuria, defined as an ACR of $\geq 300$ $\mathrm{mg} / \mathrm{g}$. The incidence of macroalbuminuria was 1.3 new cases of macroalbuminuria per 1,000 person-years, with a total of 28 cases in 21,830 person-years of follow-up in subjects with IGT, or $0.13 \%$ developing macroalbuminuria each year compared with $2.4 \%$ in patients with T2DM.

\section{Discussion}

This systematic review showed that existing evidence does not allow quantification of CKD risk in young adults aged 18-40 years with IGT/IFG compared with normoglycaemia or T2DM. Pooled estimates of CKD and a meta-analysis were not possible because most studies did not report separate results in this age group. Only one study reported the risk of CKD in young adults aged 18-40 years. The annual incidence of CKD was $0.13 \%$ per person-year compared with $2.4 \%$ in those with T2DM.

\section{Strengths of the study}

This review was not limited to the English language or geographical area and a broad range of markers was used to ascertain CKD. Furthermore, to the best of our knowledge, no systematic review has evaluated the risk of CKD in young adults aged 18-40 years with IGT/IFG compared with normoglycaemia or T2DM.

\section{Limitations of the study}

Only one study provided risk estimates of CKD in persons aged 18-40 years with IGT compared with those with T2DM. Sufficient studies were not available to conduct a meta-analysis, therefore a more generalisable and precise estimate of CKD

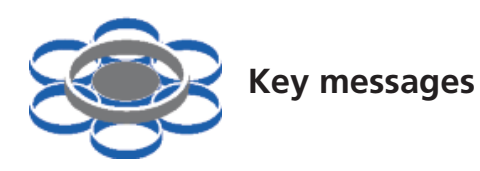

- Existing evidence does not allow quantification of CKD risk in young adults aged 18 to 40 years with IGT/IFG

- The review shows a paucity of studies exploring incidence of CKD in young adults with IGT/IFG

- The exact magnitude of CKD associated with IGT/IFG in young adults remains to be clarified

could not be presented. Furthermore, the results of this one study should be interpreted with caution because of the small sample size and study population (Pima Indians).

\section{Conclusion}

The results of this systematic review demonstrate that the risk of CKD in young adults aged $18-40$ years with IGT/IFG is lacking. Further research is needed to estimate the incidence of CKD in this cohort of individuals. To bridge this gap in evidence, large epidemiological databases may be examined to quantify the risk of CKD in young adults aged $18-40$ years with IGT/IFG compared with those with normoglycaemia.

\section{Conflict of interest None.}

Funding and Acknowledgments This review forms part of FJ's $\mathrm{PhD}$ and is funded by the National Institute for Health Research School for Primary Care Research (NIHR SPCR) studentship grant. We thank the Librarian at Barnes library, Medical School, University of Birmingham for providing assistance with the search strategy.

Authors' contributions FJ was responsible for developing the search strategy and conducting the literature search. TM and PG were involved in the design of the review. FJ performed data extraction and interpretation of the data. TM and PG provided important intellectual input and revised the manuscript critically. TM and PG read and approved the final manuscript. FJ was first reviewer, TM and PG acted as second reviewers for this systematic review. All authors read and approved the final manuscript.

PROSPERO registration: CRD42014007081

\section{References}

1. Levey A, Coresh J, Balk E, Kausz A, Levin A, Steffes M. National Kidney Foundation practice guidelines for chronic kidney disease: evaluation, classification, and stratification. Ann Intern Med 2003;139:137-47. http://dx.doi.org/10.7326/0003-4819-139-2-200307150-00013

2. Hippisley-Cox J, Coupland C. Predicting the risk of chronic kidney disease in men and women in England and Wales: prospective derivation and external validation of the QKidney Scores. BMC Fam Pract 2010;11:49. http://dx.doi.org/10.1186/1471-2296-11-49

3. Unwin N, Shaw J, Zimmet P, Alberti K. Impaired glucose tolerance and impaired fasting glycaemia: the current status on definition and intervention. Diabet Med 2002;19:708-23. http://dx.doi.org/10.1046/j.1464-5491.2002.00835.x

4. Fox CS, Larson MG, Leip EP, Meigs JB, Wilson PW, Levy D. Glycemic status and development of kidney disease: the Framingham Heart Study. Diabetes Care 2005;28:2436-40.

http://dx.doi.org/10.2337/diacare.28.10.2436

5. Tapp R, Shaw J, Zimmet P, Balkau B, Chadban S, Tonkin A. Albuminuria 
is evident in the early stages of diabetes onset: results from the Australian Diabetes, Obesity and Lifestyle Study (AusDiab). Am J Kidney Dis 2004;44:792-8. http://dx.doi.org/10.1016/S0272-6386(04)01079-0

6. Liberati A, Altman D, Tetzlaff J, Mulrow C, Gotzsche P, loannidis J. The PRISMA statement for reporting systematic reviews and meta-analyses of studies that evaluate healthcare interventions: explanation and elaboration. BMJ 2009;339:b2700. https://doi.org/10.1136/bmj.b2700

7. Stroup DF, Berlin JA, Morton SC, et al. Meta-analysis of observational studies in epidemiology: a proposal for reporting. Meta-analysis Of Observational Studies in Epidemiology (MOOSE) group. JAMA 2000; 283:2008-12. http://dx. doi.org/10.1001/jama.283.15.2008

8. Jadhakhan F, Marshall T, Gill P. A systematic review investigating the cumulative incidence of chronic kidney disease in young adults with impaired glucose tolerance. Syst Rev 2015;4:69. http://dx.doi.org/10.1186/s13643-015-0059-6

9. Buysschaert M, Bergman M. Definition of prediabetes. Med Clin North Am 2011;95:289-97, vii. http://dx.doi.org/10.1016/j.mcna.2010.11.002

10. American Diabetes Association. Diagnosis and classification of diabetes mellitus. Diabetes Care 2010;33(Suppl 1):S62-9. http://dx.doi.org/10.2337/dc10-S062

11. Hartling L, Milne A, Hamm M, Vandermeer B, Ansari M, Tsertsvadze A. Testing the Newcastle Ottawa Scale showed low reliability between individual reviewers. J Clin Epidemiol 2013;66:982-93. http://dx.doi.org/10.1016/j.jclinepi.2013.03.003

12. Higgins J, Altman D, Gotzsche P, Juni P, Moher D, Oxman A. The Cochrane Collaboration's tool for assessing risk of bias in randomised trials. BMJ 2011;343:D5928. http://dx.doi.org/10.1136/bmj.d5928

13. Begg CB, Mazumdar M. Operating characteristics of a rank correlation test for publication bias. Biometrics 1994;50:1088-101. http://dx.doi.org/10.2307/2533446

14. Egger M, Smith GD, Schneider M, Minder C. Bias in meta-analysis detected by a simple, graphical test. BMJ (Clin Res Ed) 1997:315:62934. http://dx.doi.org/10.1136/bmj.315.7109.629

15. Sterne JA, Gavaghan D, Egger M. Publication and related bias in metaanalysis: power of statistical tests and prevalence in the literature. J Clin Epidemio/ 2000;53:1119-29. http://dx.doi.org/10.1016/S0895-4356(00) 00242-0

16. Kim NH, Pavkov ME, Knowler WC, et al. Predictive value of albuminuria in American Indian youth with or without type 2 diabetes. Pediatrics 2010;125:e844-51. http://dx.doi.org/10.1542/peds.2009-1230

17. Nelson RG, Bennett PH, Beck GJ, et al. Development and progression of renal disease in Pima Indians with non-insulin-dependent diabetes mellitus. Diabetic Renal Disease Study Group. N Engl J Med 1996;335:1636-42. http://dx.doi.org/10.1056/NEJM199611283352203

18. Meigs JB, D'Agostino RB Sr, Nathan DM, Rifai N, Wilson PW. Longitudinal association of glycemia and microalbuminuria: the Framingham Offspring Study. Diabetes Care 2002;25:977-83. http://dx.doi.org/10.2337/diacare.25.6.977

19. Nelson RG, Tan M, Beck GJ, et al. Changing glomerular filtration with progression from impaired glucose tolerance to type II diabetes mellitus. Diabetologia 1999;42:90-3. http://dx.doi.org/10.1007/s001250051118

20. Nelson RG, Kunzelman CL, Pettitt DJ, Saad MF, Bennett PH, Knowler WC. Albuminuria in type 2 (non-insulin-dependent) diabetes mellitus and im- paired glucose tolerance in Pima Indians. Diabetologia 1989;32:870-6. http://dx.doi.org/10.1007/BF00297452

21. Yokoyama H, Kanno S, Takahashi S, et al. Determinants of decline in glomerular filtration rate in nonproteinuric subjects with or without diabetes and hypertension. Clin J Am Soc Nephrol 2009;4:1432-40. http://dx.doi.org/10.2215/CJN.06511208

22. Tozawa M, Iseki C, Tokashiki K, et al. Metabolic syndrome and risk of developing chronic kidney disease in Japanese adults. Hypertens Res 2007;30:937-43. http://dx.doi.org/10.1291/hypres.30.937

23. Nelson RG, Pettitt DJ, Baird HR, et al. Pre-diabetic blood pressure predicts urinary albumin excretion after the onset of type 2 (non-insulin-dependent) diabetes mellitus in Pima Indians. Diabetologia 1993;36:998-1001. http://dx.doi.org/10.1007/BF02374490

24. Rashidi A, Ghanbarian A, Azizi F. Are patients who have metabolic syndrome without diabetes at risk for developing chronic kidney disease? Evidence based on data from a large cohort screening population. Clin J Am Soc Nephrol 2007:2:976-83. http://dx.doi.org/10.2215/CJN.01020207

25. Kitiyakara C, Yamwong S, Cheepudomwit S, et al. The metabolic syndrome and chronic kidney disease in a Southeast Asian cohort. Kidney Int 2007:71:693-700. http://dx.doi.org/10.1038/sj.ki.5002128

26. Sun F, Tao Q, Zhan S. Metabolic syndrome and the development of chronic kidney disease among 118924 non-diabetic Taiwanese in a retrospective cohort. Nephrology 2010;15:84-92. http://dx.doi.org/10.1111/j.1440-1797.2009.01150.x

27. Yang $\mathrm{T}$, Chu $\mathrm{CH}, \mathrm{Hsu} \mathrm{CH}$, et al. Impact of metabolic syndrome on the incidence of chronic kidney disease: a Chinese cohort study. Nephrology 2012;17:532-8. http://dx.doi.org/10.1111/j.1440-1797.2012.01607.x

28. Kovács T, Vas T, Kovesdy CP, et al. Metabolic syndrome and other cardiovascular risk factors associated with the progression of IgA nephropathy. Clin Kidney J 2013;6:395-401. http://dx.doi.org/10.1093/ckj/sfs131

29. Watanabe H, Obata H, Watanabe T, Sasaki S, Nagai K, Aizawa Y. Metabolic syndrome and risk of development of chronic kidney disease: the Niigata preventive medicine study. Diabetes Metab Res Rev 2010;26 26-32. http://dx.doi.org/10.1002/dmrr.1058

30. Ryu S, Chang Y, Woo HY, et al. Time-dependent association between metabolic syndrome and risk of CKD in Korean men without hypertension or diabetes. Am J Kidney Dis 2009.53.59-69. http://dx.doi.org/10.1053/j.ajkd.2008.07.027

31. Jee SH, Boulware LE, Guallar E, Suh I, Appel LJ, Miller ER 3rd. Direct, progressive association of cardiovascular risk factors with incident proteinuria: results from the Korea Medical Insurance Corporation (KMIC) study. Arch Intern Med 2005;165:2299-304. http://dx.doi.org/10.1001/archinte.165.19.2299

32. Tohidi $M$, Hasheminia $M$, Mohebi $R$, et al. Incidence of chronic kidney disease and its risk factors, results of over 10 year follow up in an Iranian cohort. Plos One 2012; 7:e45304. http://dx.doi.org/10.1371/journal.pone.0045304

33. Iseki K, Ikemiya Y, Kinjo K, Iseki C, Takishita S. Prevalence of high fasting plasma glucose and risk of developing end-stage renal disease in screened subjects in Okinawa, Japan. Clin Exp Nephrol 2004;8:250-6. http://dx.doi.org/10.1007/s10157-004-0293-z 


\section{Appendix 1: Electronic search for Medline for CKD outcomes}

\begin{tabular}{|c|c|c|}
\hline Count & Searches & Results \\
\hline 1 & exp Renal Insufficiency Chronicl & 84840 \\
\hline 2 & chronic kidney disease.mp. & 18247 \\
\hline 3 & chronic kidney disease\$.mp. & 18745 \\
\hline$\underline{4}$ & exp Kidney Failure, Chronic/ & 78448 \\
\hline$\underline{5}$ & chronic kidney failure.mp. & 975 \\
\hline 6 & chronic kidney failure\$.mp. & 976 \\
\hline$\underline{7}$ & chronic renal failure.mp. & 20307 \\
\hline 8 & chronic renal failure\$.mp. & 20319 \\
\hline 9 & end stage kidney disease.mp. & 997 \\
\hline 10 & end stage kidney disease\$.mp. & 1005 \\
\hline 11 & esrd.mp. & 9767 \\
\hline 12 & esrd\$.mp. & 9769 \\
\hline 13 & chronic kidney insufficiency.mp. & 195 \\
\hline 14 & chronic kidney insufficiency\$.mp. & 195 \\
\hline 15 & end stage renal disease.mp. & 19454 \\
\hline 16 & end stage renal disease\$.mp. & 19625 \\
\hline 17 & end stage renal failure.mp. & 4888 \\
\hline 18 & end stage renal failure\$.mp. & 4891 \\
\hline 19 & kidney failure.mp. & 81179 \\
\hline 20 & kidney failure\$.mp. & 81828 \\
\hline 21 & renal insufficiency/ & 10919 \\
\hline 22 & renal failure.mp. & 71184 \\
\hline 23 & renal failure\$.mp. & 71271 \\
\hline 24 & kidney insufficiency.mp. & 577 \\
\hline 25 & kidney insufficiency\$.mp. & 577 \\
\hline$\underline{26}$ & exp renal dialysis/ & 93204 \\
\hline 27 & renal dialysis.mp. & 74276 \\
\hline$\underline{28}$ & renal dialysis\$.mp. & 74276 \\
\hline 29 & extracorporeal dialysis.mp. & 161 \\
\hline 30 & extracorporeal dialysis\$.mp. & 162 \\
\hline 31 & hemodialysis.mp. & 47033 \\
\hline 32 & hemodialysis\$.mp. & 47039 \\
\hline 33 & haemodialysis.mp. & 11565 \\
\hline 34 & haemodialysis\$.mp. & 11576 \\
\hline 35 & exp peritoneal dialysis/ & 22761 \\
\hline 36 & peritoneal dialysis.mp. & 26208 \\
\hline 37 & peritoneal dialysis\$.mp. & 26210 \\
\hline 38 & renal disease.mp. & 39428 \\
\hline 39 & renal disease\$.mp. & 43692 \\
\hline$\underline{40}$ & exp kidney diseases/ & 414228 \\
\hline$\underline{41}$ & kidney disease.mp. & 30990 \\
\hline$\underline{42}$ & kidney disease $\$ . m p$. & 103750 \\
\hline$\underline{43}$ & nephropathy.mp. & 37719 \\
\hline$\underline{44}$ & nephropathy\$.mp. & 37721 \\
\hline 45 & exp diabetic nephropathies/ & 19707 \\
\hline 46 & diabetic nephropathy.mp. & 11909 \\
\hline$\underline{47}$ & diabetic nephropathy\$.mp. & 11909 \\
\hline
\end{tabular}

\begin{tabular}{|c|c|c|}
\hline Count & Searches & Results \\
\hline 48 & exp kidney transplantation/ & 79900 \\
\hline 49 & kidney transplantation.mp. & 81478 \\
\hline 50 & kidney transplantation\$.mp. & 81539 \\
\hline 51 & renal transplant.mp. & 18888 \\
\hline 52 & renal transplant $\$ . \mathrm{mp}$. & 36596 \\
\hline 53 & exp dialysis/ & 22124 \\
\hline 54 & dialysis.mp. & 132315 \\
\hline 55 & dialysis\$.mp. & 132329 \\
\hline 56 & exp renal insufficiency/ & 127094 \\
\hline 57 & renal insufficiency.mp. & 33560 \\
\hline 58 & renal insufficiency \$.mp. & 33571 \\
\hline 59 & EGFR.mp. & 27296 \\
\hline 60 & EGFR \$.mp. & 27669 \\
\hline 61 & exp glomerular filtration rate/ & 33096 \\
\hline 62 & glomerular filtration rate.mp. & 42765 \\
\hline 63 & glomerular filtration rate\$.mp. & 43111 \\
\hline 64 & exp creatinine/ & 46991 \\
\hline 65 & creatinine.mp. & 95418 \\
\hline 66 & creatinine\$.mp. & 95673 \\
\hline 67 & serum creatinine.mp. & 26670 \\
\hline 68 & serum creatinine\$.mp. & 26781 \\
\hline 69 & serum creatinine clearance.mp. & 53 \\
\hline 70 & serum creatinine clearance $\$ . m p$. & 58 \\
\hline 71 & exp albuminuria/ & 12045 \\
\hline 72 & albuminuria\$.mp. & 14614 \\
\hline 73 & exp proteinuria/ & 32445 \\
\hline 74 & proteinuria.mp. & 36905 \\
\hline 75 & proteinuria\$.mp. & 36921 \\
\hline \multirow[t]{10}{*}{76} & 1 or 2 or 3 or 4 or 5 or 6 or 7 or 8 or 9 or 10 or & 683333 \\
\hline & 11 or 12 or 13 or 14 or 15 or 16 or 17 or 18 or & \\
\hline & 19 or 20 or 21 or 22 or 23 or 24 or 25 or 26 or & \\
\hline & 27 or 28 or 29 or 30 or 31 or 32 or 33 or 34 or & \\
\hline & 35 or 36 or 37 or 38 or 39 or 40 or 41 or 42 or & \\
\hline & 43 or 44 or 45 or 46 or 47 or 48 or 49 or 50 or & \\
\hline & 51 or 52 or 53 or 54 or 55 or 56 or 57 or 58 or & \\
\hline & 59 or 60 or 61 or 62 or 63 or 64 or 65 or 66 or & \\
\hline & 67 or 68 or 69 or 70 or 71 or 72 or 73 or 74 or & \\
\hline & 75 & \\
\hline 77 & exp diabetes mellitus, type $2 /$ & 87630 \\
\hline 78 & diabetes mellitus type $2 . \mathrm{mp}$. & 87782 \\
\hline 79 & type 2 diabetes.mp. & 60366 \\
\hline 80 & type 2 diabetes $\$ . m p$. & 60434 \\
\hline 81 & niddm.mp. & 6673 \\
\hline 82 & niddm\$.mp. & 6704 \\
\hline 83 & exp diabetes insipidus/ & 7011 \\
\hline 84 & diabetes insipidus.mp. & 8589 \\
\hline 85 & diabetes insipidus\$.mp. & 8589 \\
\hline
\end{tabular}




\section{Appendix 1: Electronic search for Medline for CKD outcomes (continued)}

\begin{tabular}{|c|c|c|}
\hline Count & Searches & Results \\
\hline 86 & 77 or 78 or 79 or 80 or 81 or 82 or 83 or 84 or 85 & 113193 \\
\hline 87 & exp glucose intolerance/ & 6360 \\
\hline 88 & impaired glucose tolerance.mp. & 8065 \\
\hline 89 & impaired glucose tolerance \$.mp. & 8066 \\
\hline$\underline{90}$ & glucose intolerance.mp. & 11300 \\
\hline$\underline{91}$ & glucose intolerance\$.mp. & 11302 \\
\hline$\underline{92}$ & exp prediabetic state/ & 3852 \\
\hline$\underline{93}$ & prediabetes.mp. & 1633 \\
\hline 94 & prediabetic state.mp. & 4004 \\
\hline 95 & prediabetic state\$.mp. & 4053 \\
\hline 96 & exp blood glucose/ & 130285 \\
\hline$\underline{97}$ & blood glucose.mp. & 147811 \\
\hline$\underline{98}$ & blood glucose\$.mp. & 147841 \\
\hline 99 & glucose metabolism.mp. & 23463 \\
\hline 100 & glucose metabolism\$.mp. & 23713 \\
\hline 101 & exp glucose tolerance test/ & 29397 \\
\hline 102 & glucose tolerance test.mp. & 33799 \\
\hline 103 & glucose tolerance test\$.mp. & 34976 \\
\hline 104 & OGTT.mp. & 5382 \\
\hline 105 & OGTT\$.mp. & 5481 \\
\hline 106 & exp Hyperglycemia/ & 26636 \\
\hline 107 & hyperglycemia.mp. & 37642 \\
\hline 108 & hyperglycemia\$.mp. & 37682 \\
\hline 109 & hyperglycaemia.mp. & 6827 \\
\hline 110 & hyperglycaemia\$.mp. & 6840 \\
\hline 111 & impaired fasting glucose.mp. & 2336 \\
\hline 112 & impaired fasting glucose\$.mp. & 2336 \\
\hline 113 & postprandial hyperglycemia.mp. & 911 \\
\hline 114 & postprandial hyperglycaemia.mp. & 283 \\
\hline 115 & exp hemoglobin a, glycosylated/ & 23254 \\
\hline 116 & hemoglobin a, glycosylated.mp. & 23255 \\
\hline 117 & hemoglobin a, glycosylated\$.mp. & 23255 \\
\hline 118 & Haemoglobin a, glycosylated.mp. & 1 \\
\hline 119 & HbA1c.mp. & 13678 \\
\hline 120 & HbA1c\$.mp. & 13741 \\
\hline 121 & glycemic abnormality.mp. & 7 \\
\hline 122 & Glycaemic abnormality.mp. & 0 \\
\hline
\end{tabular}

\begin{tabular}{|c|c|c|}
\hline 123 & Fasting plasma glucose.mp. & 7250 \\
\hline 124 & Fasting plasma glucose $\$ . \mathrm{mp}$. & 7259 \\
\hline \multirow[t]{5}{*}{125} & 87 or 88 or 89 or 90 or 91 or 92 or 93 or 94 or 95 or & 223393 \\
\hline & 96 or 97 or 98 or 99 or 100 or 101 or 102 or 103 or & \\
\hline & 104 or 105 or 106 or 107 or 108 or 109 or 110 or 111 & \\
\hline & or 112 or 113 or 114 or 115 or 116 or 117 or 118 or & \\
\hline & 119 or 120 or 121 or 122 or 123 or 124 & \\
\hline 126 & 76 and 86 and 125 & 4367 \\
\hline 127 & exp cohort studies/ & 1387399 \\
\hline 128 & cohort\$.tw. & 263907 \\
\hline Count & Searches & Results \\
\hline 129 & controlled clinical trial.pt. & 88411 \\
\hline 130 & epidemiologic methods/ & 29569 \\
\hline 131 & exp case-control studies/ & 688110 \\
\hline 132 & (case\$ and control\$).tw. & 311313 \\
\hline 133 & 127 or 128 or 129 or 130 or 131 or 132 & 1909067 \\
\hline 134 & cohort studies/ & 170386 \\
\hline 135 & longitudinal studies/ & 87299 \\
\hline 136 & follow-up studies/ & 504746 \\
\hline 137 & prospective studies/ & 376036 \\
\hline 138 & retrospective studies/ & 512412 \\
\hline 139 & cohort.ti,ab. & 239106 \\
\hline 140 & longitudinal.ti,ab. & 132074 \\
\hline 141 & prospective.ti,ab. & 339467 \\
\hline 142 & retrospective.ti, ab. & 264289 \\
\hline 143 & Case-Control Studies/ & 188791 \\
\hline 144 & Control Groups/ & 1435 \\
\hline 145 & Matched-Pair Analysis/ & 4154 \\
\hline 146 & retrospective studies/ & 512412 \\
\hline \multirow[t]{2}{*}{147} & ((case* adj5 control*) or (case adj3 comparison*) & 374925 \\
\hline & or control group*).ti,ab. & \\
\hline \multirow[t]{3}{*}{148} & 127 or 128 or 129 or 130 or 131 or 132 or 133 or & 2266708 \\
\hline & 134 or 135 or 136 or 137 or 138 or 139 or 140 or & \\
\hline & 141 or 142 or 143 or 144 or 145 or 146 or 147 & \\
\hline 149 & 126 and 148 & 1563 \\
\hline 150 & Remove duplicates from 149 & 1560 \\
\hline
\end{tabular}




\section{Appendix 2: Review eligibility criteria checklist}

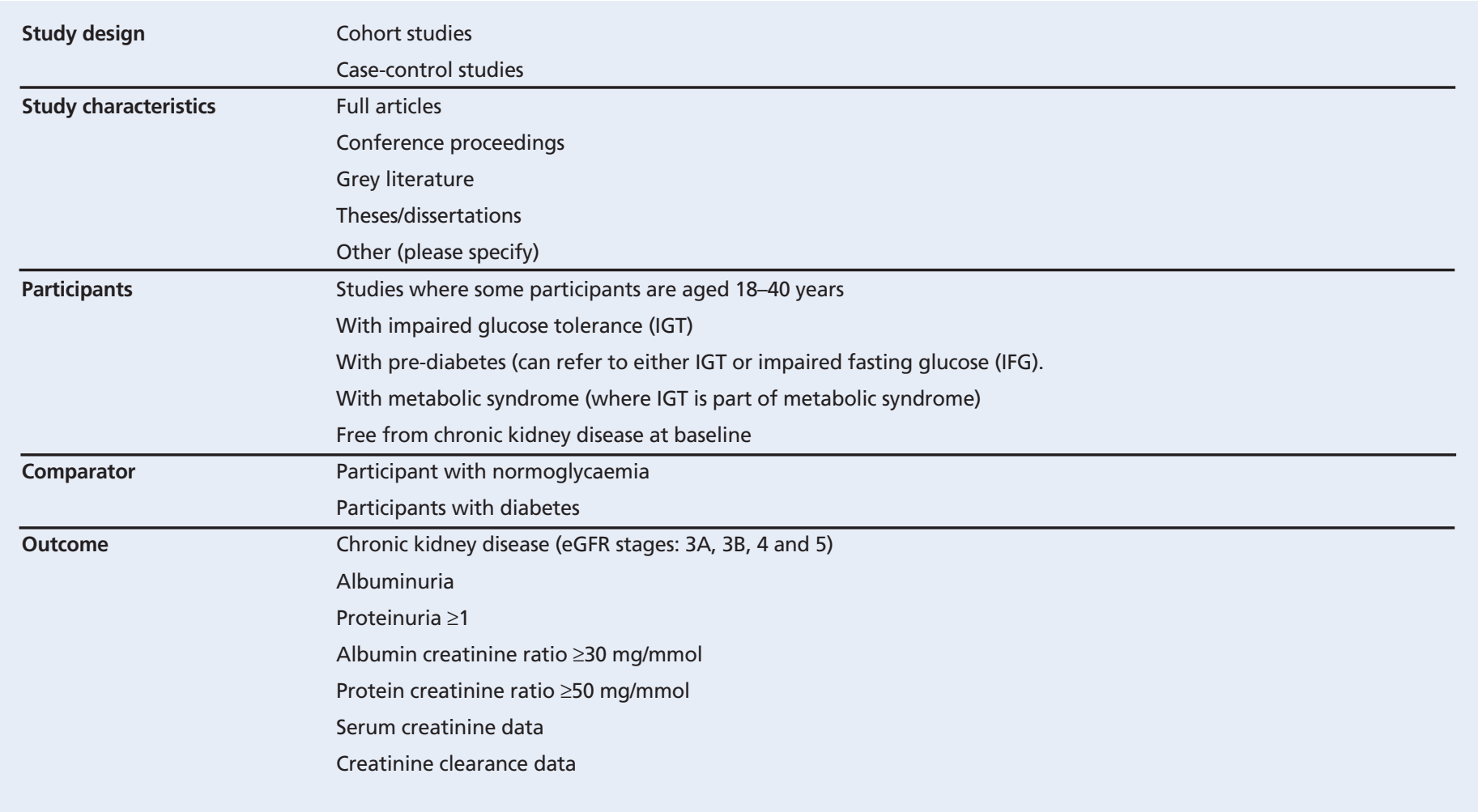




\section{Appendix 3: Quality assessment form adapted from Ottawa-Newcastle scale (NOS) for assessing non-randomised studies}

\begin{tabular}{|c|c|c|}
\hline & & Yes/No/Unclear \\
\hline $\begin{array}{l}\text { Adequate description of } \\
\text { study population }\end{array}$ & $\begin{array}{l}\text { [1] Was the study population well characterised? } \\
\text { - Age } \\
\text { - Sex } \\
\text { - Ethnicity } \\
\text { - Suitable definition of IGT/IFG }\end{array}$ & \\
\hline $\begin{array}{l}\text { Validated method to } \\
\text { confirm outcome }\end{array}$ & $\begin{array}{l}\text { [1] Were valid and reliable measures used to ascertain outcome? For example, } \\
\begin{array}{|ll|}\text { Stage } & \text { eGFR }\left(\mathrm{ml} / \mathrm{min} / 1.73 \mathrm{~m}^{2}\right) \\
1 & \geq 90 \\
2 & 60-89 \\
3 \mathrm{~A} & 45-59 \\
3 \mathrm{~B} & 30-44 \\
4 & 15-29 \\
5 & <15 \\
\mathrm{ACR}>30 \mathrm{mg} / \mathrm{mmol} \\
\mathrm{PCR}>45 \mathrm{mg} / \mathrm{mmol} \\
\mathrm{SCr} \text { measures } \\
\mathrm{CrCl} \text { measures }\end{array}\end{array}$ & \\
\hline $\begin{array}{l}\text { Completeness of } \\
\text { follow-up (attrition) }\end{array}$ & $\begin{array}{l}\text { [1] Were drop-out rates and reasons for drop-out similar across exposed and unexposed? } \\
\text { [2] Were numbers of drop-outs/withdrawals documented at each time point? }\end{array}$ & \\
\hline $\begin{array}{l}\text { Analysis controls for } \\
\text { confounding }\end{array}$ & [1] Does the study identify and control for important confounding variables and effect modifiers? & \\
\hline Sample size calculated & $\begin{array}{l}\text { [1] Is the sample size adequate? } \\
\text { [2] Did the study describe how the sample size was calculated? } \\
\text { - Did the investigators conduct a power analysis to determine the adequacy of study group sizes for the out- } \\
\text { come of interest? } \\
\text { - Was the sample size large enough to detect differences in event or a significant OR/RR between groups? } \\
\text { Mean ( } \pm \text { SE) change in GFR }\end{array}$ & \\
\hline $\begin{array}{l}\text { Analytical methods } \\
\text { appropriate }\end{array}$ & $\begin{array}{l}\text { [1] Was the kind of analysis done appropriate for the kind of outcome data? For example, } \\
\text { Dichotomous - logistic regression, survival analysis } \\
\text { Categorical - mixed model for categorical outcomes } \\
\text { Continuous - mixed model, ANCOVA } \\
\text { Mean change ( } \pm \text { SE) } \\
\text { [2] Was loss to follow-up accounted for in the analysis (for example, through sensitivity analysis)? }\end{array}$ & \\
\hline
\end{tabular}

Overall appraisal:

Include

Exclude

Seek further info

Comments (including reasons for exclusion): 